\title{
Academic Supervision of Supervisor in Improving Teachers Pedagogic Competences at Melati Cluster in Banda Aceh
}

\author{
Muzayyin $^{1 *}$, Murniati ${ }^{2}$, Niswanto ${ }^{3}$ \\ ${ }^{1}$ Master of Education Administration, Syiah Kuala University, Indonesia \\ ${ }^{2}$ Universitas Syiah Kuala, Indonesia. \\ *Corresponding email: ayien694@gmail.com
}

Received: 08 April 2021

Accepted: 13 July 2021

Published: 30 August 2021

Abstract: The aim of this research is to obtain complete and accurate data of school about academic Supervision of Supervisor in Improving Teachers Pedagogic Competences at Melati Cluster in Banda Aceh. This study used descriptive method with a qualitative approach. The data collection technique was conducted by observation, interview, and documentation study. The instrument used in this research is interview guidelines. The subjects of this study were supervisors, principal, and teachers. The result of this study shows that (1) Supervision programs were settled relying on the evaluation of the previous year supervision. It was established individually at the beginning of the academic year. Academic supervision program that is teacher training in planning, implementing and assessing learning outcomes. (2) The supervision done by school supervisor has been effective relying on the technique and procedures. The technique applied is individual and group techniques (3) Academic supervision followup by school supervisor has been efficient and effective where at the end of the supervision as reports were there for teachers to read. Supervisors hold forum events like workshop, so it will help in improving the pedagogic competence.

Keywords: academic supervision, pedagogic competence, Banda Aceh.

Abstrak: Penelitian ini bertujuan untuk memperoleh data sekolah yang lengkap dan akurat tentang Supervisi Akademik Supervisor dalam Peningkatan Kompetensi Pedagogik Guru di Gugus Melati Banda Aceh. Penelitian ini menggunakan metode deskriptif dengan pendekatan kualitatif. Teknik pengumpulan data dilakukan dengan observasi, wawancara, dan studi dokumentasi. Instrumen yang digunakan dalam penelitian ini adalah pedoman wawancara. Subjek penelitian ini adalah supervisor, kepala sekolah, dan guru. Hasil penelitian ini menunjukkan bahwa (1) Program supervisi diselesaikan dengan mengandalkan evaluasi supervisi tahun sebelumnya. Itu didirikan secara individual pada awal tahun akademik. Program supervisi akademik yaitu pelatihan guru dalam merencanakan, melaksanakan dan menilai hasil pembelajaran. (2) Supervisi yang dilakukan oleh pengawas sekolah sudah efektif dengan mengandalkan teknik dan prosedur. Teknik yang diterapkan adalah teknik individu dan kelompok. (3) Tindak lanjut supervisi akademik oleh pengawas sekolah sudah efisien dan efektif dimana pada akhir supervisi sudah ada laporan untuk dibaca guru. Supervisor mengadakan acara forum seperti workshop, sehingga akan membantu dalam meningkatkan kompetensi pedagogik.

Kata kunci: supervisi akademik, kompetensi pedagogi, Banda Aceh.

\section{To cite this article:}

Muzaiyyin., Murniati., \& Niswanto. (2021). Academic Supervision of Supervisor in Improving Teachers Pedagogic Competences at Melati Cluster in Banda Aceh. Jurnal Pendidikan Progresif, 11(2), 430 437. doi: 10.23960/jpp.v11.i2.202123. 


\section{INTRODUCTION}

The quality of education is a high-quality standard limit which must be fulfilled in education according to the expectation (Chonjo, 2018; Mosha, 2018; Guskova, 2016). The quality considered in education including the quality of input, process, output, and outcome. Input is considered excellent if it is ready to process, as the process is considered having a good quality if it could create a learning condition that active, creative, and fun. The output is excellent if the learning result of academic and nonacademic learning is good, and a high quality outcome is when it quickly accepted in the real world (Quinlan \& Hone, 2020; Montrieux, Raes, \& Schellens, 2017; Tan \& Decena, 2017).

The learning process in education is closely related to the teachers; teachers are the educator and mentor who teach a useful thing in the school organization as well as outside the organization (Lawrence, \& Tar, 2018; Viloria et.al., 2018; Taylor, 2017). Teachers in school organization expected to truly execute their assigned duties or show a good performance, and own the competences as a teacher. Teachers' competence is the ability, knowledge, and attitude which has to be learned, mastered, and possessed as a guide by teachers in performing their responsibilities in their occupation (Abid \& Hussain, 2017; From, 2017; Mantra, 2017).

Teachers' performance is indicated by how far a teacher could meet the competences, which includes the pedagogical competence, personality competence, social competence, and professional competence (Meier, \& Beushausen, 2019; Bartholomew et.al., 2018; Kamenju et.al., 2016). One of the teacher competences is pedagogical competence. The pedagogical competence is directly connected to the students in the classroom. Pedagogical competence is teachers' ability in managing the student learning process. The pedagogical competence is one of the essential competencies that must be possessed by a teacher since it related to the quality of a lesson and with this competence the quality of education could be achieved. This competence is also the one that unique and has its own characteristic, which makes the teacher is distinguished and different from other occupations (Yürekli Kaynardað, 2019; Kamerilova et.al., 2018; Diep \& Hartmann, 2016).

To ensure teachers' pedagogical competence, a person in charge is required in this case. One of them is a supervisor of education. The duties of a school supervisor include carrying out the supervision, both the academic supervision and managerial supervision. Supervision that directly associated with pedagogical competence is academic supervision. The academic supervision is supervision that helps and guides the teachers to develop their ability in learning.

The academic supervision targets are helping and guiding teachers in planning their learning activities, implementing the lesson plan, assessing the process and output of the lesson, using the result as a guide in improving the lesson, and giving a correct and consistent feedback for the students, service the students who encounter any learning difficulties, providing additional tutor for the students, providing a fun learning atmosphere, using instructional media, improving the learning interaction (models, strategies, techniques, approaches, etc.) that appropriate and useful, and developing a learning innovation.

The aim of this research is to obtain complete and accurate data of school about academic supervision of supervisor in improving teachers pedagogic competences at Melati Cluster in Banda Aceh.

\section{THEORETICAL FRAMEWORK}

\section{The concept of educational supervision}

The educational supervision perceived as an activity of improving and fixing the quality of process and result of a learning process. In this 
context, supervision serves to improve the professional ability of the teacher which leads to an improvement in the quality of the learning process and result. Therefore, the supervisor's responsibilities are supervising, guiding, developing, and assessing the personal activities performed in a school.

Even though the term supervision means something that translated as surveillance or monitoring, but in principle, the term supervision specifically means helping and guiding the teachers in their effort to improve the quality of education. Supervision is professional monitoring in the academic field which implemented based on the scientific principles about its field of work, comprehend the learning activity deeper than just a regular supervisor. Meanwhile, the Carter Good's Dictionary of Education. Supervision is every effort of assigned school's official that leads to the provision of leadership for the teachers and other educators in teaching improvement, including stimulation of professional growth and improvement of the teachers, selection and revision of educational goals, teaching materials, and teaching methods as well as teaching evaluation (Callender \& Lenz, 2018; DiPaola, \& Wagner, 2018).

The academic supervision is a series of activities of helping teachers improving their ability in achieving the learning objectives and the essence of academic supervision is entirely not limited about assessing teachers performance in managing the learning process, but helping the teachers develop their professional abilities. The overall central of supervision essentially boils down to the academic supervision, since the main activity of education in a school is the academic activities, while other activities such as managerial and administrative activities are the instruments to achieve the main activities.

\section{School supervisor}

The school supervisor is a subject in implementing the academic supervision besides the headmaster. To be assigned as a supervisor of a school or a madrasah, one should meet all requirements of a school/ madrasah supervision that applies nationally. These standards include the qualification standard and supervisor competence standard. In the supervisor competency standard, the managerial supervision and academic supervision competencies are explained in the point no 2 and 3. A supervisor is any person responsible for working with others to increase the effectiveness of the teachinglearning situation.

The supervisor has to show his/her ability in implementing the academic supervision planning as well as benefited by the result. The supervisor is responsible for guiding the teachers in becoming a high-quality educator and tutor. Therefore, a supervisor is expected to have various supervision techniques in the execution guided by the principles of supervision.

The supervisor competencies include personality competence, managerial supervision competence, academic supervision competence, educational evaluation competence, research development competence, and social competence

\section{Teachers' Pedagogical Competence}

Teachers' competence is teachers' ability in implementing the duties responsibly and properly. The competences possessed by each teacher would show the quality of a teacher in teaching. These competencies would be manifested in the mastery of knowledge and professionalism in implementing the functions as a teacher. This means that the teacher does not only have to be smart but also able to transfer the knowledge to the students

The pedagogical competence is explained, including: to master the knowledge and the foundation of knowledge, to implement the principles of education and learning process, and to become proficient in the cultural foundation in educational praxis. 
Teachers' pedagogical competence is the ability to manage students' lesson which includes understanding the students, planning and implementing the lesson, evaluating the result of a lesson, and encouraging the development of students to actualize any potential talent they had.

\section{- METHODS}

This research adopted a descriptive method with a qualitative approach. The descriptive method meant to assess the circumstance, condition or other things which result is described as a research report. Qualitative research is the methods to explore and comprehend the meaning that for some other people or group perceived as it comes from a social or humanitarian problem. In this case, the research emphasizes in the plan, implementation, and the follow-up by the school supervisor who is in charge of supervising teachers' pedagogical competence at schools categorized under the Melati cluster in Banda Aceh. The location of this study is SDN 20 Banda Aceh, SDN 36 Banda Aceh and SDN 65 Banda Aceh which is included in the Melati Cluster of Kuta Alam Subdistrict of Banda Aceh City.

The subjects in this study were supervisors, principals and teachers. Data collection techniques about supervisors' academic supervision in improving teacher pedagogical competence are interview guidelines, observation guidelines, and documentation studies, by asking questions that have been formulated in accordance with research questions. Data analysis was carried out in three steps, namely (1) data reduction; (2) display; and (3) drawing conclusions and verification.

The credibility test is carried out to strengthen the trust and validity of the findings in the field. Data credibility or trustworthiness tests on qualitative research results include, among others, (1) extended observations (2) increased persistence in research (3) triangulation (4) negative case analysis (5) using reference material and (6) member check. The credibility test of this research uses triangulation by checking from several sources, namely the principal, teachers and documentation.

\section{RESULTS AND DISCUSSION}

In this section, the author will discuss the result of research which explains the core of the research outcome obtained from the research process.

\section{The academic supervision program by the school supervisor}

The academic supervision program is arranged based on the evaluation result of last years' supervision, arranged individually at the beginning of the school year and the execution is scheduled. In another word, this program is already been arranged before. Afterward, the planning process is conducted which is preparing the supervision instruments. Preparing supervision instruments is an essential thing to do. Before the supervisor executes his/her duties, the supervisor will cooperate with the headmaster in assessing and observing teachers' administration.

The academic supervision program is a teacher coaching program, in planning, executing and assessing the result of a lesson. The assistance programs in improving teachers' ability in arranging the lesson plan include: compiling the yearly program and semester program based on the syllabus and content standard, improving lesson plan, deciding the minimal completeness criteria of a specific class, and improving teaching materials. The assistance programs to improve teachers' ability in the learning implementation process are the scientific integrative thematic learning, development of learning models, completes learning, remedial and enrichment program. The assistance program guide the teachers in improving the ability to assess student learning result, including: the use of communication and information technology (ICT) in the 
assessment, provision of assessment guidelines, technical guidelines for the assessment design, arrangement of minimal completeness criteria, knowledge assessment, psychomotor assessment, affective assessment, portfolio assessment, development of question items, discussion of exam outline, analysis of question items, analysis of basic competence and supplementary program, and preparation of class action research proposals.

In the planning process, a supervisor needs to be able to map everything related to his duties as a school supervisor, including the curriculum, school facilities and infrastructures, teachers and other things linked to the school environment. The planning process of academic supervision program is very important since good planning could provide a clear illustration to achieve the goals and ease the process of assessing success. The planning process in education management function is a necessary part and one of the functions included in the first stage. Likewise, planning the academic supervision program at a school belongs in a vital position in a series of academic supervision processes.

\section{The academic supervision implementation by the school supervisor}

In the implementation stage, a school supervisor implements the scheduled supervision process with the teachers as prearranged in the planning program. There is a pre-observation stage which in this stage the supervisor collaboration with headmaster will check teachers' learning administration using the supervision instruments prepared. The headmaster will singly review teachers' learning administration from the educational calendar, yearly program, a semester program, effective week calculation, learning syllabus, lesson plan, minimal completeness criteria, the analysis of evaluation items, et cetera.
Moreover, there is an agreement between a supervisor and teachers according to the arranged schedule. Supervisor conducts the observation in class based on the instruments prepared before. Next, there will be another meeting to evaluate and both praises and convey the shortcomings, teachers also would selfintrospect by telling some weakness to the supervisor. The function of the supervisor here is not to find any mistakes but to accompany and guide. The existence of a supervisor is expected by the teachers.

The aspect observed in the instruments of learning activity is the preliminary activities and closing activities; the preliminary activities include apperception and motivation, and explanatory of competencies and activity plans. These activities contain mastery of learning material, implementation of education learning strategies, implementation of a scientific approach, the use of learning resources and media in the learning process, and the use of proper language in the learning process. The closing activities include the reflection process and summary involving the students, provision of oral and written test, collection of work outcome as portfolio materials and implementation of follow-up by giving the instruction of next activities and enrichment tasks.

The school supervisor uses an approach in executing the supervision program. The approaches are varying both individually or as a group. Individually, supervision is conducted by participating in the classroom and evaluating the learning process which further will be directed individually. Meanwhile, the approach as a group is conducted if a similar problem is encountered by the teachers, such as inability to use IT and not proficient yet to use a learning resource.

The individual supervision technique used by a supervisor in implementing the supervision of learning program directly touches teachers' activities in teaching. This individual supervision 
is indeed more focused on academic supervision; even the use is not limited to the managerial supervision. The activities are classroom visit, classroom observation, inter-visitation, and selfassessment.

After implementing the observation process, several obstacles were found related to pedagogical competence. Based on the findings of research obtained in the field, it is indicated that the pedagogical competence categorized as inadequate and still need more development, both related to the learning strategy, mastering the classroom, and developing teaching materials as well as the use of media.

Other obstacles are teachers' lack of ability in mastering the way to practicing and implementing the knowledge to the students, which means they still teach by giving a lecture/ speech, and unable to use the discussion method optimally, so students become inactive.

From various techniques of supervision, the academic supervision techniques including classroom visit, individual talk, and group discussion are assumed to be more useful, although it does not mean that other techniques are ruled out. The supervisor could adapt the supervision technique with the learning problem encountered by the teachers. This effort will help in improving teachers' quality as well as the quality of students' learning outcome in achieving the quality and purpose of education.

\section{The academic supervision follow-up by the school supervisor}

The last stage of academic supervision is the follow-up process, which in this case the supervisor engages with specific teachers to show the observation result of the teacher's teaching process in the classroom. After finishing all of it, teachers are welcomed to sign a prepared instrument. At this opportunity, a supervisor could give the coaching/ guidance. However, if the problem encountered by the teacher deemed heavy and require joint training, the headmaster would conduct group coaching, for example by holding a workshop. The follow-up implemented also explained in the meeting such as teacher working group. The flaws and weaknesses found will be further followed up it this specific forum.

Other follow-ups for the teachers would be attending training in the cluster by the cluster facilitator or regional facilitator. One of them is cluster Melati which located in Banda Aceh. Other things that could be done in implementing the follow-ups are through a recommendation process for a teacher who still stumbles upon an obstacle by the headmaster. This process is one of the forms of cooperation between supervisor and headmaster. Thus, for further assistance, there should be cooperation from a headmaster so teachers' problems could be solved.

The success of a follow-up process could be perceived by the improvement of a teacher in overcoming their weaknesses, for instance by a teacher competency testing which certainly would affect the certification process of a particular teacher. A certification could not be obtained if the competence is still lacking.

The result of supervision has to be followedup in order to give a real impact on improving teachers' professionalism. This real impact is expected to reach the people as well as the stakeholders. This particular follow-up includes reinforcement and appreciation to the teachers who meet the standard, educational admonition for the teachers who still not meet the standard yet, and an opportunity to attend further training/ upgrading. The follow-up based on the analysis result is the utilization of supervision result. The follow-up of supervision result is further guidance and the establishment of instruments.

\section{CONCLUSIONS}

At the planning stage, it can be concluded that this stage is already effective where the school supervisor already prepare the assessment 
instrument when conducting the supervision at the classroom. The supervision implementation program arranged based on the evaluation result of last year's academic supervision and individually arranged at the beginning of the academic year. The academic supervision programs are guiding teachers in planning, implementing, and assessing the learning outcome. Before conducting a supervision process, a supervisor collaborates with the headmaster. The headmaster first assesses and observes the administration of a teacher. This process is to minimalize further flaws when supervision is conducted by the supervisor.

The first stage of the implementation of supervision conducted by the supervisor is to check learning administration of a teacher using the supervision instrument which already prepared beforehand. Furthermore, in the observation stage, the school supervisor observes a process concerning the way of using media and how the knowledge is transferred by the teacher to the students. The process of observing the learning activities from the beginning to the end utilize the classroom observation instrument. School supervisor adopted an approach in supervising both individually and as a group. In implementing the supervision process it was found that the pedagogical competence is categorized as inadequate and still need further guidance, both related to teaching strategy, mastering the classroom, and developing teaching materials, as well as the use of media.

The implementation of follow-up of the academic supervision by school supervisor is considered as effective and efficient, where each end of supervision resulting in reports that could be read by the teachers. If the problem encountered by the teacher deemed heavy and require joint training, school supervisor would conduct a group coaching, such as through a workshop and attending a training in the cluster by the cluster facilitator or regional facilitator. This effort is expected to help in improving teacher' pedagogical competence.

\section{REFERENCES}

Abid, N., \& Hussain, T. (2017). Subject Matter Knowledge Competence: An Empirical Evidence of Elementary School Teachers. Bulletin of Education and Research, 39(1), 245-250.

Bartholomew, K. J., Ntoumanis, N., Mouratidis, A., Katartzi, E., Thøgersen-Ntoumani, C., \& Vlachopoulos, S. (2018). Beware of your teaching style: A school-year long investigation of controlling teaching and student motivational experiences. Learning and Instruction, 53, 50-63.

Callender, K. A., \& Lenz, A. S. (2018). Implications for Wellness Based Supervision and Professional Quality of Life. Journal of Counseling \& Development, 96(4), 436-448.

Chonjo, P. N. (2018). The quality of education in Tanzanian primary schools: An assessment of physical facilities and teaching learning materials. Utafiti Journal, 1(1).

Diep, P. C., \& Hartmann, M. (2016). Green Skills in Vocational Teacher Education-a model of pedagogical competence for a world of sustainable development. TVET@ Asia, 6, 1-19.

DiPaola, M., \& Wagner, C.A. (2018). Improving instruction through supervision, evaluation, and professional development. IAP.

From, J. (2017). Pedagogical Digital Competence-Between Values, Knowledge and Skills. Higher Education Studies, 7(2), 43-50.

Guskova, N. D., Vdovin, S. M., Krakovskaya, I. N., \& Slushkina, Y. Y. (2016). The quality of education as a primary concern of the sustainable development.

Kamenju, J., Mwisukha, A., Elijah, R., \& 
Muthomi, H. (2016). Kenya Teacher Trainee Athletes' Awareness of Selected Performance-Enhancing Substances and Their Effects to Sports Performance. Journal of Physical Education, 3(2), 2338.

Kamerilova, G. S., Kartavykh, M. A., Ageeva, E. L., Gordeeva, I. A., Astashina, N. I., \& Ruban, E. M. (2018). Communicative teaching models: The formation of the professional pedagogical competence among health and safety school teachers. Espacios, 39(29), 7.

Lawrence, J. E., \& Tar, U. A. (2018). Factors that influence teachers' adoption and integration of ICT in teaching/learning process. Educational Media International, 55(1), 79-105.

Mantra, I. B. N. (2017). Promoting primary school teachers' competence through dynamic interactive workshop and partnership. International journal of linguistics, literature and culture, 3(1), 16.

Meier, B., \& Beushausen, U. (2019). Long-term effects of a voice training program to prevent voice disorders in teachers. Journal of Voice.

Montrieux, H., Raes, A., \& Schellens, T. (2017). 'The best app is the teacher'Introducing classroom scripts in technology enhanced education. Journal of Computer Assisted Learning, 33(3), 267-281.

Mosha, H. (2018). The state and quality of education in Tanzania: Areflection. Papers in Education and Development, (31).

Quinlan, D. M., \& Hone, L. C. (2020). The Educators' Guide to Whole-school Wellbeing: A Practical Guide to Getting Started, Best-practice Process and Effective Implementation. Routledge.
Tan, J. W., \& Decena, R. A. (2017). ACCESSQUALITY MODEL IN HIGHER EDUCATION. NMSCST Research Journal, 3(1).

Taylor, E. W. (2017). Transformative learning theory. In Transformative learning meets bildung (pp. 17-29). Brill Sense.

Viloria, A., Lis-Gutiérrez, J. P., Gaitán-Angulo, M., Godoy, A. R. M., Moreno, G. C., \& Kamatkar, S. J. (2018, June). Methodology for the design of a student pattern recognition tool to facilitate the teaching-learning process through knowledge data discovery (big data). In International Conference on Data Mining and Big Data (pp. 670-679). Springer, Cham.

Yürekli Kaynardað, A. (2019). Pedagogy in HE: does it matter?. Studies in Higher Education, 44(1), 111-119. 